\title{
UTILIZATION OF EUCHEUMA COTTONII AND EUCHEUMA SPINOSUM FLOUR IN NARROW-BARRED SPANISH MACKEREL MEATBALLS
}

\author{
Jeremia Manuel*, Melanie Cornelia, William Wijaya \\ Food Technology Department, Universitas Pelita Harapan, Indonesia \\ *e-mail: jeremia.halim@uph.edu
}

\begin{abstract}
Narrow-barred Spanish mackerel (Scomberomorus spp.) is a species of fish that is widely preferred due to its high potential and economical value. This research is aimed to utilize seaweed (Eucheuma cottonii and Eucheuma spinosum) to increase iodine and dietary fiber content of fish meatballs to help fulfill the daily needs of Indonesians. The first stage of this research was conducted to determine the best type and concentration of seaweed flour to be added to the fish meatballs dough. A series of seaweed flour addition concentration employed in this research are 1, 2, 3, 4, and 5\% for each type of seaweed separately. Several factors put into consideration when selecting the best seaweed addition concentration were moisture content, texture, and organoleptic tests (scoring and hedonic). Through moisture content, gel strength, and organoleptic analysis, 2\% Eucheuma cottonii was chosen to be added. Second stage of this research was conducted to compare the chosen meatball with control. The chosen fish meatball has better profile of moisture, fat, ash, carbohydrate, dietary fiber, and iodine content compared to control. Dietary fiber and iodine content analysis showed that the chosen fish meatball contain $0.0046 \%$ dietary fiber and $102 \mathrm{mcg} / 100 \mathrm{~g}$ iodine.
\end{abstract}

Keywords: Narrow-barred Spanish mackerel, Eucheuma cottonii, Eucheuma spinosum, iodine content, dietary fiber

\section{INTRODUCTION}

Narrow barred Spanish mackerel (Scomberomorus commerson) is enjoyed by society as food having high economic value (Mutakin 2001). The habitat they lived in is vast ocean, moving from one place to another, eating small fishes such as sardines. It can be found oftenly in Indo Pacific and Indian oceans. It can grow to approximately $183 \mathrm{~cm}$ and $27 \mathrm{~kg}$ (Saanin 1984).

Seaweed is one of food materials with high content of iodine and dietary fiber. There are three classes of seaweed, named Chlorophyceae (green algae), Rhodophyceae (red algae), and Phaeophyceae (brown algae). Eucheuma cottonii and Eucheuma spinosum are Rhodophyceae (red algae) that can be found in Indonesian waters. They have high economic value as they are the source of carrageenan. These seaweeds are often cultivated in the archipelago of Kepulauan Seribu and Riau; Lampung, Celebes, and Bali. These regions have calm sea current so that the productivity of seaweed can be enhanced (Poncomulyo et al. 2003).

According to Winarno (1996), iodine content in brown algae and red algae, consecutively are around $0.1-0.8 \%$ and $0.1-0.15 \%$. In an effort to battle against Gangguan Akibat Kurang lodium (GAKI) in Indonesia, an attempt to optimize the utilization of seaweed should be done. 
This research is aimed to utilize seaweed (Eucheuma cottonii and Eucheuma spinosum) to raise iodine and dietary fiber content of narrow barred Spanish mackerel meatballs. The product resulted is expected to be able to fulfill the need of iodine and dietary fiber in Indonesia society.

\section{MATERIALS AND METHODS}

\section{Materials}

Main materials used for this research included narrow barred Spanish mackerel obtained from Pasar Puri Indah, fresh seaweed (Eucheuma cottonii and Euchuema spinosum) obtained from the archipelago of Kepulauan Seribu, is dried using drum drier, milled, and sieved (80 mesh). The other materials included: tapioca flour, ice cubes, sodium tripolyphosphate (STPP), salt, sugar, pepper, and mono sodium glutamate (MSG).

Materials used for analysis included benzene, selenium catalyst, $\mathrm{K}_{2} \mathrm{SO}_{4}, \mathrm{H}_{2} \mathrm{SO}_{4} \mathrm{H}_{2} \mathrm{O}_{2}$, boric acid, $\mathrm{NaOH}, \mathrm{HCl}$, distilled water, petroleum ether, buffer $\mathrm{Na}_{2} \mathrm{PO}_{4} \mathrm{pH}$ 6, enzyme termamyl, pepsin, pancreatin, ethanol, acetone, amyl alchohol, cetyl trimethylammonium chloride, acetonitrile, KI, MES-TRIS (Buffer pH 8,2), $\alpha$-Amylase, Protease, Amyloglucosidase.

\section{Method}

\section{Stage 1}

The purpose of stage 1 is to obtain the best type and concentration of seaweed flour to be used in the making of fish meatballs. Two types of seaweed were used (e.g. Eucheuma cottonii and Eucheuma spinosum) and added in the concentration of 1, 2, 3, 4, and $5 \%$. Complete randomized factorial design (two factors) was used with two times repetition. The flowchart of making fish meatball can be seen on Figure 1, meanwhile the formulation can be seen on Table 1.

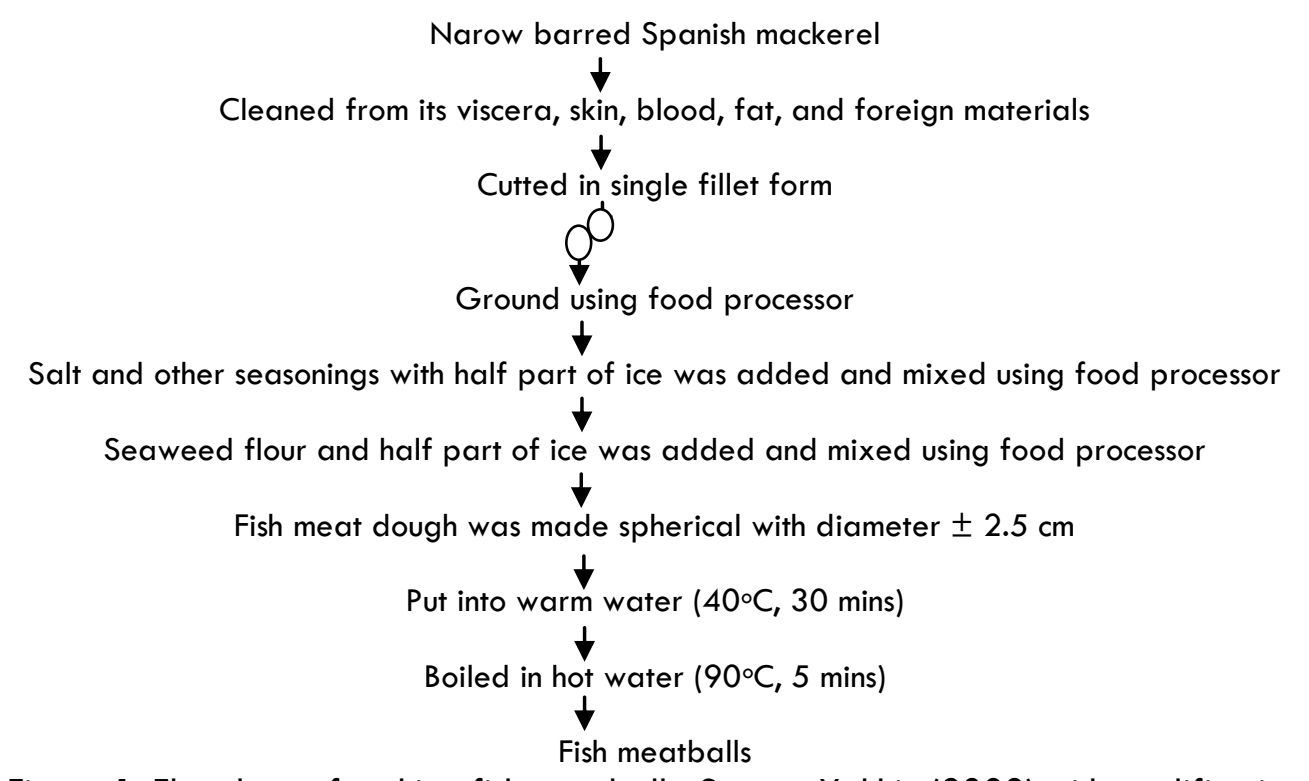

Figure 1. Flowchart of making fish meatballs. Source: Yakhin (2008) with modification

Table 1. Fish meatballs formulation 


\begin{tabular}{lr}
\hline \multicolumn{1}{c}{ Materials } & Amount $(\mathrm{g})$ \\
\hline Fish meat & 100.00 \\
Tapioca flour & 10.00 \\
lce & 20.00 \\
Salt & 2.0 \\
Sugar & 0.10 \\
Pepper & 0.25 \\
STPP & 0.50 \\
MSG & 0.10 \\
Seaweed flour & As treatment* \\
\hline $2,3,4,5 \%$ (based on fish meat amount) \\
$(2008)$, with modification
\end{tabular}

Organoleptic test (scoring and hedonic) was done based on some parameters (color, aroma, taste, off-taste, and general acceptance). Water content was analyzed using oven method (AOAC 934.01 2005). Gel strength was analyzed using texture analyzer (TA.XT Plus Texture Analyzer) with ball probe 10 and test speed $5 \mathrm{~mm} / \mathrm{sec}$.

Stage 2

Stage 2 aims to determine proximate composition, iodine and dietary fiber content of the chosen meatballs from stage 1. The chosen fish meatball was compared with control fish meatballs (without seaweed flour addition).

Some of the parameters assayed included water content using oven method (AOAC 934.01 2005), fat content using soxhlet method (AOAC 963.15 2005), ash content using furnace method (AOAC 938.08 2005), protein content using Kjeldahl method (AOAC 940.25 2005), carbohydrate method using by difference method, iodine content using HPLC method (AOAC 992.22 2006), and total dietary fiber using enzymatic-gravimetric method (AOAC $991.432005)$.

\section{RESULT AND DISCUSSION}

\section{Main Materials Characteristic}

Main materials that become focus of the research are narrow barred Spanish mackerel and seaweed flour. The yields of seaweed powder obtained from dried seaweed are $50.63 \%$ and $36.54 \%$, consecutively for Eucheuma cottonii and Eucheuma spinosum. Moisture content of dried seaweed and its powder are $37.53 \%$ and $17.00 \%$ for Eucheuma cottonii; and $55.96 \%$ and $18.81 \%$ for Eucheuma spinosum. Heating process, which is done using double drum drier during seaweed powder making, caused the moisture content to decrease. Meanwhile the yield of narrow barred Spanish mackerel that is used in meatballs making ranged around $450-880$ gram per fish, with the percent yield of fish fillet is $68.03 \%$.

\section{Characteristics of Fish Meatballs in Addition of Seaweed Flour}

\subsection{Moisture Content}


Moisture content is one of the components that determine the quality of fish meatballs. Less moisture content means longer shelf-life of a product. It is determined by boiling time and the raw material used in the meatballs. During boiling process, the raw materials will bind water, resulting in high moisture content. The result ranged from $76.61 \%$ to $78.81 \%$, with Eucheuma cottonii having lower moisture content than Eucheuma spinosum, although not significant at $\alpha=0.05$. Overall, moisture content of meatballs produced are comply with the requirements set in SNI, which determine $80 \%$ as the maximum moisture content.

\subsection{Gel Strength Characteristics}

Gel strength analysis using texture analyzer (TA-XT Plus, Stable Micro System) showed that there is no significant effect of seaweed flour type toward the gel strength. Meanwhile there was an effect of seaweed flour concentration toward the gel strength as can be seen in Figure 2. The result shows that higher concentration of seaweed flour will increase gel strength of meatballs. The texture of high gel strength resulted in elastic and cohesive meatballs. The compound responsible for this gel strength is kappa-carageenan that is contained in seaweed flour (Imerson 2000).

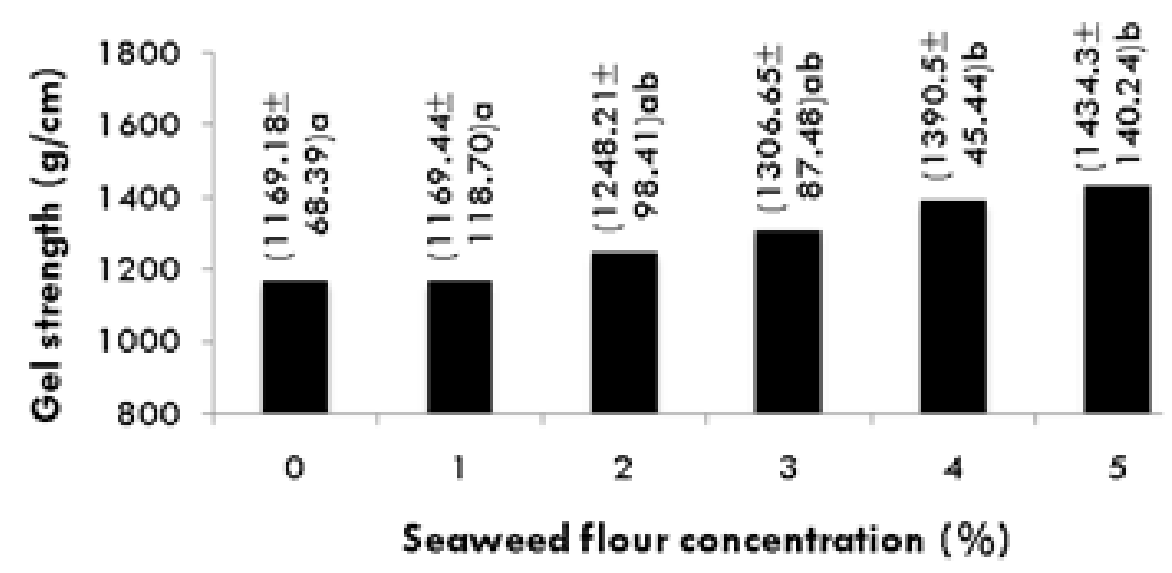

Note: different letter after numbers indicated significant difference $(p>0.05)$

Figure 2. Effect of seaweed flour concentration toward meatball gel strength

\section{Organoleptic Characteristics}

Parameters used for scoring and hedonic test include: color, aroma, taste, off-flavor and general acceptance. Table 2 and Table 3 consecutively show the result of scoring test and hedonic test. There is no interaction between type and concentration of seaweed flour. Furthermore, type of seaweed flour do not affect the score of color, aroma, flavor, and offflavor at $\alpha=0.05$.

Color scoring ranged from 2.93 to 3.97 . It indicates that the colors of meatballs assessed are white to a little off-white. Generally the addition of seaweed flour to meatballs formulation will darken the products to a little off-white. Aroma and taste scoring consecutively ranged from 3.03 to 3.87 and from 3.17 to 3.87 , which indicates the ability of panelist to detect fishy aroma and taste. Meanwhile off-flavor scores are quite low, ranged from 2.87 to 3.93, which shows that the addition of seaweed flour doesn't affect the flavor significantly. 
Table 2. Score of organoleptic parameters in various formulations

\begin{tabular}{cllll}
\hline $\begin{array}{c}\text { Seaweed flour } \\
\text { Addition }\end{array}$ & Color & Aroma & Taste & Off-flavor \\
\hline Control 0\% & $3.97^{\mathrm{a}}$ & $3.83^{\mathrm{a}}$ & $3.73^{\mathrm{ab}}$ & $3.93^{\mathrm{a}}$ \\
Seaweed 1\% & $3.60^{\mathrm{b}}$ & $3.70^{\mathrm{ab}}$ & $3.77^{\mathrm{a}}$ & $3.92^{\mathrm{a}}$ \\
Seaweed $2 \%$ & $3.37^{\mathrm{bc}}$ & $3.52^{\mathrm{abc}}$ & $3.55^{\mathrm{abc}}$ & $3.60^{\mathrm{ab}}$ \\
Seaweed 3\% & $3.15^{\mathrm{cd}}$ & $3.23^{\mathrm{c}}$ & $3.28^{\mathrm{cd}}$ & $3.42^{\mathrm{b}}$ \\
Seaweed 4\% & $3.17^{\mathrm{cd}}$ & $3.37^{\mathrm{bc}}$ & $3.45^{\mathrm{bcd}}$ & $3.28^{\mathrm{b}}$ \\
Seaweed 5\% & $2.93^{\mathrm{d}}$ & $3.37^{\mathrm{bc}}$ & $3.20^{\mathrm{d}}$ & $3.22^{\mathrm{b}}$ \\
\hline
\end{tabular}

Note: different superscript indicated significant difference $(p>0.05)$ among the same parameter

Table 3. Hedonic value of organoleptic paramaters in various formulations

\begin{tabular}{ccccc}
\hline $\begin{array}{c}\text { Seaweed flour } \\
\text { addition }\end{array}$ & Color & Aroma & Taste & $\begin{array}{c}\text { Overall } \\
\text { acceptance }\end{array}$ \\
\hline Control 0\% & $5.76^{\mathrm{a}}$ & $5.53^{\mathrm{a}}$ & $5.73^{\mathrm{a}}$ & $5.63^{\mathrm{a}}$ \\
Seaweed 1\% & $5.34^{\mathrm{b}}$ & $5.19^{\mathrm{b}}$ & $5.42^{\mathrm{b}}$ & $5.45^{\mathrm{a}}$ \\
Seaweed $2 \%$ & $5.16^{\mathrm{b}}$ & $4.96^{\mathrm{b}}$ & $5.13^{\mathrm{c}}$ & $5.1^{\mathrm{b}}$ \\
Seaweed 3\% & $4.66^{\mathrm{c}}$ & $4.56^{\mathrm{c}}$ & $4.41^{\mathrm{d}}$ & $4.2^{\mathrm{c}}$ \\
Seaweed 4\% & $4.29 \mathrm{~d}$ & $4.29^{\mathrm{d}}$ & $4.30^{\mathrm{d}}$ & $4.23^{\mathrm{d}}$ \\
Seaweed 5\% & $4.11^{\mathrm{d}}$ & $4.01^{\mathrm{e}}$ & $3.82^{\mathrm{e}}$ & $3.79 \mathrm{e}$ \\
\hline
\end{tabular}

Note: different superscript indicated significant difference $(p>0.05)$ among the same parameter

From Table 3, it can be seen that type of seaweed flour added to the formulation do not affect the liking score of color, aroma, taste, and overall acceptance significantly at $\alpha=0.05$. The range score of liking given by panelists toward color, aroma, taste, and general acceptance consecutively are 4.27 to $5.76 ; 4.01$ to $5.53 ; 3.74$ to $5.74 ; 3.70$ to 5.73 , with a comsistent trend. This result shows that generally the panelists position toward the products are from neutral to like. The more seaweed flour added, the less it is preferred by the panelists.

\section{Comparison Between Chosen Fish Meatball with Control and Standard}

From the result of Stage I, the chosen seaweed flour type and concentration chosen to be added is Eucheuma cottonni 2\%. In Stage II, the chosen formulation will be compared against control (meatballs without seaweed flour addition) and SNI. Chemical analyses done included moisture content, fat content, protein content, ash content, carbohydrate content, dietary fiber content and iodine content. The result can be seen in Table 4.

Table 4. Chosen fish meatballs characteristics compared to SNI and control (without seaweed)

\begin{tabular}{|c|c|c|c|c|c|c|c|}
\hline Formulation & $\begin{array}{c}\text { Moisture } \\
(\%)\end{array}$ & $\begin{array}{l}\text { Fat } \\
(\%)\end{array}$ & $\begin{array}{l}\text { Protein } \\
(\%)\end{array}$ & $\begin{array}{l}\text { Ash } \\
(\%)\end{array}$ & $\begin{array}{c}\text { Carbohydrate } \\
(\%)\end{array}$ & $\begin{array}{c}\text { Dietary } \\
\text { Fiber } \\
(\%)\end{array}$ & $\begin{array}{l}\text { lodine content } \\
\text { (mcg/100mg) }\end{array}$ \\
\hline $\mathrm{SNI} *$ & $\begin{array}{l}\text { Maks } \\
80.0\end{array}$ & $\begin{array}{c}\text { Maks } \\
1.0\end{array}$ & $\begin{array}{l}\text { Min } \\
9.0\end{array}$ & $\begin{array}{c}\text { Maks } \\
3.0\end{array}$ & - & - & - \\
\hline $\begin{array}{l}\text { Control } \\
\text { meatball }\end{array}$ & 78.64 & 2.51 & 12.61 & 1.70 & 4.56 & 0.0027 & 95.28 \\
\hline $\begin{array}{l}\text { Chosen } \\
\text { meatball }\end{array}$ & 76.16 & 2.28 & 12.49 & 1.59 & 7.47 & 0.0046 & 102.16 \\
\hline
\end{tabular}

According to Table 4, the chosen meatball has slightly lower moisture content $(76.16 \%)$, compared to control $(78.64 \%)$. This might be caused by kappa karagennan inside the seaweed powder can bind with more water molecules. Moisture content will affect the shelflife of meatballs. According to SNI 01-3819-1995, moisture content of the chosen meatball 
fulfills the requirements stated, which is max. $80 \%$. Fat content of chosen meatball $(2.28 \%)$ is also lower than control $(2.51 \%)$. It is because of lower fat content provided by seaweed (Winarno 1996). The same trend can also be seen on protein content and ash content.

The chosen meatball is higher only in carbohydrate composition $(7.47 \%)$, compared to control (4.56\%). This is obvious, since seaweed flour contribute to the carbohydrate content. According to Winarno (1996), seaweed is rich in its dietary fiber content. It is calculated as carbohydrate in fish meatballs. Dietary fiber content of the chosen meatball (46 ppm) is slightly higher than the control (27 ppm). Fish meatball is not a good source of dietary fiber, since the components do not contain dietary fiber. There is only slight increase of dietary fiber, since that concentration of seaweed added is only $2 \%$ of the total composition. It does not contribute much to the meatball.

lodine content of chosen meatball $(102.16 \mathrm{mcg} / 100 \mathrm{~g})$ is higher than the control $(95.28$ $\mathrm{mcg} / 100 \mathrm{~g}$ ). The result shows that the addition of seaweed flour (Eucheuma cottonii $2 \%$ ) can be used as iodine source in fish meatball. Indonesian AKG (Angka Kecukupan Gizi) advise teenager and adult (from 10 years old to 60 years old) to consume averagely $150 \mathrm{mcg}$ of iodine per day (Depkes RI 1994). Consuming approximately $147 \mathrm{gram}$ of the chosen meatball can fulfill the AKG.

\section{CONCLUSION}

The chosen formulation was decided from moisture content, gel strength, and organoleptic analysis. Meatball with the addition of $2 \%$ Eucheuma cottonii flour was chosen for the next stage. In comparison with control meatball (without seaweed addition), the chosen meatball has higher composition of iodine and carbohydrate, which can be attributed to dietary fiber content. Further research can be done to obtain higher concentration of dietary fiber and iodine. Extraction step toward the seaweed can be done to obtain the proper fraction. Meanwhile, higher concentration of seaweed flour will darken the meatballs, thus the discoloration need to be prevented.

\section{REFERENCES}

AOAC. 2005. Official Methods of Analysis of the Association of Official Analytical Chemists. USA: AOAC, Inc.

CNS Farnell. 2001. Manual of LFRA Texture Analyzer. 
Depkes RI. 1994. Angka Kecukupan Gizi yang Dianjurkan Bagi Bangsa Indonesia. Keputusan Menkes RI No. 322/Menkes/SK/IV/1994.

DSN. 1995. Bakso lkan: SNI 01 -3819-1995. Jakarta: Dewan Standarisasi Nasional.

Imeson A. 2000. Carrageenan. In Handbook of Hydrocolloids. G.O. Philips and P.A. Williams (ed). Boca Raton: CRC Press.

Mutakin J. 2001. Analisis Potensi dan Musim Penangkapan Ikan Tenggiri (Scomberomorus spp.) di Pangandaran Kabupaten Ciamis, Jawa Barat. [Skirpsi]. Bogor : Institut Pertanian Bogor, Fakultas Perikanan dan Ilmu Kelautan.

Poncomulyo T, Maryani H, Kristiani L. 2003. Budi Daya dan Pengolahan Rumput Laut. Tanggerang: Agromedia pustaka.

Saanin H. 1984. Taksonomi dan Kunci Identifikasi Ikan. Vol I dan II. Bandung: Bina Cipta.

Slamet DS, Mahmud MK, Muhilal, Fardiaz D, Simarmata JP. 1990. Pedoman Analisis Zat Gizi. Jakarta: Departemen Kesehatan Republik Indonesia.

Sulaiman A, Anwar F, Rimbawan, Marliyati SA. 1993. Metode Analisis Komposisi Zat Gizi Makanan. Bogor: Institut Pertanian Bogor.

Winarno FG. 1996. Teknologi Pengolahan Rumput Laut. Jakarta: Sinar Pustaka Harapan.

Yakhin L. 2008. Pengaruh penambahan kappa-karagenan terhadap karakteristik bakso ikan nila hitam (Oreochromis niloticus) dan bakso ikan lele dumbo (Clarias gariepinus). [skripsi]. Tangerang: Fakultas Teknologi Industri, Universitas Pelita Harapan. 